\title{
ASSESSMENT OF NUCLEAR SAFETY AND NUCLEAR CRITICALITY POTENTIAL IN THE DEFENSE WASTE PROCESSING FACILITY (U)
}

by

B. C. $\mathrm{Ha}$

Westinghouse Savannah River Company

Savannah River Site

Aiken, South Carolina 29808

This paper was prepared in connection with work done under the above contract number with the U. S.

Department of Energy. By acceptance of this paper, the publisher and/or recipient acknowledges the U.S. Government's right to retain a nonexclusive, royalty-free license in and to any copyright covering this paper, along with the right to reproduce and to authorize others to reproduce all or part of the copyrighted paper. 


\section{DISCLAIMER}

This report was prepared as an account of work sponsored by an agency of the United States Government. Neither the United States Goveinment nor any agency thereof, nor any of their employees, makes any warranty, express or implied, or assumes any legal liability or responsibility for the accuracy, completeness, or usefulness of any information, apparatus, product, or process disclosed, or represents that its use would not infringe privately owned rights. Reference herein to any specific commercial product, process, or service by trade name, trademark, manufacturer, or otherwise does not necessarily constitute or imply its endorsement, recommendation, or favoring by the United States Government or any agency thereof. The views and opinions of authors expressed herein do not necessarily state or reflect those of the United States Government or any agency thereof.

This report has been reproduced directly from the best available copy.

Available to DOE and DOE contractors from the Office of Scientific and Technical Information, P. O. Box 62, Oak Ridge, TN 37831; prices available from (615) $576-8401$.

Available to the public from the National Technical Information Service, U. S. Department of Commerce, 5285 Port Royal Rd., Springfield, VA 22161. 
WESTINGHOUSE SAVANNAH RIVER COMPANY INTER-OFFICE MEMORANDUM

WSRC-RP-93-692

Revision 0

Keywords: DWPF, Nuclear Safety, Nuclear Criticality.

Retention Time: Lifetime

CC:

L. M. Papouchado, 773-A E. W. Holtzscheiter, 773-A

J. F. Ortaldo, 704-S

L. F. Landon, 704-T

J. A. Gentilucci, 704-S

W. S. Durant, 992 W-1

H. H. Elder, 704-S

J. H. Gray, 773-A

A. G. Sarrack, 992-1W

T. G. Williamson, $773-42 \mathrm{~A}$

C. T. Randall, 704-T

J. T. Carter, 704-1T

M. D. Boersma, 704-T

R. E. Eibling, 704-T

J. R. Fowler, 704-Z

R. A. Jacobs, 704-T

J. F. Mincey, 773-22A

N. H. Kuehn, 773-42A

N. E. Bibler, 773-A

W. T. Goldston, 704-S

D. A. Sharp, 992W-1

DC\&RM, 773-52A (1)

Glass Technology Group (14)

May 10, 1993

To: $\quad$ M. J. Plodinec, 773-A

From: $\quad$ B. C. Ha, 773-A B\& \&f

ASSESSMENT OF NUCLEAR SAFETY AND NUCLEAR CRITICALITY POTENTIAL IN THE DEFENSE WASTE PROCESSING FACILITY (U)

\section{Summary}

A panel of experts in the fields of process engineering, process chemistry, and safety analysis met together on January 26, 1993 and February 19, 1993, to discuss nuclear safety and nuclear critically potential in the Defense Waste Processing Facility (DWPF) processes. They included M. D. Boersma (DWPT), W. S. Durant (NPSR), R. E. Eibling (DWPT), H. H. Elder (DWPF), J. R. Fowler (DWPF), J. H. Gray (CTS), B. C. Ha (DWPT), R. A. Jacobs (DWPT), and A. G. Sarrack (NPSR). 
Nuclear safety issues and potential sources of nuclear criticality incidents in the DWPF were examined in depth. The discussion started at the receipt of slurry feeds: the Low Point Pump Pit Precipitate Tank (LPPPPT) and the Low Point Pump Pit Sludge Tank (LPPPST), and went through all DWPF processes. The potential for criticality incidents in the DWPF is minimal, except for the following:

(1) The DWPF Salt Processing Cell (SPC), Chemical Process Cell (CPC), and Melt Cell (MC). They are being addressed in a DWPF Technology Issue, T.I. 24.1.

(2) The DWPF process vent and off-gas systems. Documentation of the reasons why solids accumulation in the vent system in the DWPF will not pose citicality concerns is required.

(3) Waste Treatment Area. Documentation of fate of solids in the Recycle Collection Tank (RCT), and in liquid products from the dissolution of HEME and HEPA spent filter elements in the Decontamination Waste Treatment Tank (DWTT) is required.

(4) Mercury Purification Cell. Although it is not part of item (1) above, analysis is required to resolve the Technology Issue T.I. 24.1 .

(5) The Late Wash Facility. The filtration system needs to be investigated once the design is complete.

The above five issues are also believed to have a minimum potential for nuclear safety and criticality incidents. However, referenciable information is needed to more firmly establish the safety of these systems.

\section{Introduction}

A panel of experts in the fields of process engineering, process chemistry, and safety analysis met together on January 26, 1993, and February 19, 1993 to discuss nuclear safety and nuclear criticality potential in the Defense Waste Processing Facility (DWPF) processes. They represent the Defense Waste Processing Technology Section (DWPT), the Chemical Technology Section (CTS), and the Nuclear Process Safety Research Section (NPSR) of the Savannah River Technology Center (SRTC), and the DWPF process engineers. DWPT is the SRTC section responsible for supporting the DWPF, and is familiar with the process engineering and process chemistry of the DWPF processes. CTS supports the SRS separation areas and has extensive experience with nuclear safety issues related to chemical processes that are used to process nuclear material. The DWPF 
process engineers were at the meeting to provide detailed process and operational information. The NPSR deals with safety analysis of all nuclear processes at the SRS, and know the types of questions that need to be asked, and the concerns that need to be addressed.

Following is a list of people who attended the two meetings: M. D. Boersma (DWPT), W. S. Durant (NPSR), R. E. Eibling (DWPT), H. H. Elder (DWPF), J. R. Fowler (DWPF), J. H. Gray (CTS), B. C. Ha (DWPT), R. A. Jacobs (DWPT), and A. G. Sarrack (NPSR). E. W. Holtzscheiter, manager of DWPT, also attended the meeting briefly to provide guidance.

Nuclear safety issues and possibilities of nuclear criticality incidents in the DWPF were examined in depth. The discussion started at the receipt of slurry feeds: the Low Point Pump Pit Precipitate Tank (LPPPPT) and the Low Point Pump Pit Sludge Tank (LPPPST), and went into detail the whole DWPF processes. The following assumptions were used during the discussions:

(1) The slurry feeds from Tank Farm to the DWPF are inherently safe with respect to nuclear safety and nuclear criticality. This assumption allows us to ignore the possibilities of accumulation of fissile material in piping and transfer systems. Unless a mechanism exists to separate fissile material from the bulk solids (precipitate and sludges), nuclear criticality is impossible. Throughout the discussion, we have only looked at process areas in which chemical and physical interactions might separate fissile materials from bulk solids that could then accumulate in a configuration that could cause a nuclear criticality incident.

(2) No oxalic acid will be used in the DWPF process cells. If oxalic acid is introduced into the DWPF processes later, its effects must be analyzed and documented. The nuclear criticality issues would then need to be re-examined.

(3) There is no isotopic separation (and enrichment) mechanism in the DWPF processes.

Following is a discussion of each of the areas and processes of the DWPF in terms of potential nuclear safety issues and nuclear criticality concerns.

\section{Low Point Pump Pit Precipitate Tank (LPPPPT), Low Point Pump Pit Sludge Tank (LPPPST), Piping and Slurry Transfer Systems}

These systems were examined in detail. However, there is no known physical or chemical mechanism for separation of fissile material from the bulk solids (precipitate and sludges) in these systems. Nuclear 
criticality is thought to be impossible in these systems and subsequent piping and slurry transfer systems. Thus they are inherently safe, with respect to nuclear criticality, since the bulk solids are inherently safe. Nuclear criticality is not an issue in the LPPPPT, the LPPPST or the piping and related transfer systems.

\section{Late Wash Facility}

It is recommended that the Late Wash Facility be analyzed for nuclear safety after the design is complete. Of particular concern is the filtration system where solids are accumulated. Analysis must show that either (1) fissile material will not be separated from the bulk solids, either chemically or physically; or (2) if separation and accumulation does occur, nuclear criticality is impossible due to unfavorable geometry or other factors.

The analysis of the Late Wash Facility will be similar to that of the InTank Precipitation's filtration system, and should use the same sources of information.

\section{Salt Process Cell (Precipitate Hydrolysis Process)}

The Precipitate Hydrolysis Process (PHP) was discussed in detail. This is one of the places where chemical reactions and processes potentially could separate and accumulate fissile material in an unsafe configuration, with respect to nuclear criticality. The precipitate slurry fed to the Salt Process Cell poses no nuclear safety concern in the form delivered fiom the waste tanks 1 . As documented in reference 1 , the maximum loading of uranium and plutonium on monosodium titanate (MST) is below the individual infinitely safe limits for plutonium and uranium. However, the MST may be altered by the process reaction conditions and uranium and plutonium may not remain bound to the MST. Experimental data is needed to establish if uranium and plutonium is dissolved or remains with the insoluble solids at the end of the hydrolysis reaction $(\mathrm{pH}=2-4)$. If the uranium and plutonium are in solution, then there is no nuclear safety concern because the concentrations are very low $2-5$.

It is assumed that uranium and plutonium will separate from MST, but remain insoluble for worst case scenarios. It should be mentioned that the content of the precipitate reactor feed tank (PRFT) is always safe, because of the inherent safety of the slurry before any processing is done. For the following cases where there might be potential nuclear incidents, it is assumed that there will be no isotopic separation, and hence no isotope enrichment. The bounding cases of these scenarios, which are addressed in the current DWPF Technology Issue T.I. 24.1, will be analyzed and documented by a certified nuclear criticality 
specialist. The uranium and plutonium concentration will be those reported by Fowler (References 2 to 5 ) for batches 1 through 4 .

(1) Fouling .

In this scenario, the precipitate hydrolysis reactions have gone into unexpected directions, and significant fouling of the cooling coils in the PR by tars has occurred. The fissile material, mainly uranium and plutonium, is assumed to be distributed uniformly in a 1/4-inch layer of tar on the coils in the precipitate hydrolysis reactor (PR). Since this situation happened in the previous reference HAN process where four precipitate hydrolysis batches were processed before fouling was discovered, the total amount of fissile material will be assumed to be an accumulation of four batches. 6 Fouling is not thought possible under the current late washing precipitate hydrolysis process. It will be used as the worst case scenario, an upset or abnormal condition which could be monitored and detected by tracking of the heat transfer coefficient of the PR cooling coils 7 .

(2) Accumulation of Fissile Material due to Loss of Agitation.

In this scenario, fissile material separates from MST and settles at the bottom of the PR or precipitate hydrolysis bottom tank (PRBT). It will be assumed that agitation was lost at the end of one batch, fissile material settles uniformly to the bottom of these tanks with other solids, and another batch has been transferred into the vessel, causing accumulation of two batches of fissile material. It is believed that total amount of fissile material in two PR batches (and also two PRBT batches), will not cause a nuclear safety concern. This determination will be documented in T.I. 24.1. The nuclear safety analysis may be performed to determine whether the geometry of the PR and PRBT is nuclear criticality safe or not, or if the total amount of fissile material in 2 PR batches (and 2 PRBT batches) can cause a nuclear safety concern.

The total number of PR and PRBT batches that could cause a concern about accumulating a critical mass of fissile material due to loss of agitation will also be determined, and documented. This would provide a basis but is not a credible scenario, since loss of agitation is a process upset condition, which would be detected before processing of more than two batches is completed.

(3) Accumulation of Fissile Material in Sump.

Process leaks, spills, and floor flushes in the Salt Process Cell (SPC) are collected in sump collection systems. Both aqueous 
and organic solutions will be collected. The remote sump pump should discharge back to the PR for processing. A direct jumper route from the sump pump to the Formic Acid Waste Header and the Hot Decontaminated Waste Header is also provided for future use if required. This direct jumper will discharge the sump into the Recycle Collection Tank (RCT).

In the worst case scenario the entire contents of both the PR and the PRFT are discharged onto the floor and collected in the sump. A nuclear criticality incident is not expected to be possible, based on the total amount of fissile material in these two tanks. This determination will be documented in the T.I. 24.1 .

For the scenario where solid material accumulates in the sump over time, there is a lot of uncertainty, and not enough information. The total number of PR and/or PRFT batches that would have to be spilled over a period of time to accumulate a critical mass in the sump will be determined to form a basis for later assessment. Two-year worth of precipitate hydrolysis feed, which is approximately equivalent to a sludge batch, will be used as the upper bound in calculations.

\section{(4) Accumulation in Condenser/Decanter}

During the steam distillation portion of the precipitate hydrolysis reaction cycle, an equivalent of 4 lbs of water per pound of insoluble solids fed to the reactor is evaporated into the precipitate hydrolysis condenser decanter (PRCD). Aqueous flows from the decanter (PRCD) back to the reactor; and organic overflows to the organic evaporator (OE).

Accumulation of fissile material in the PRCD was thought possible due to steam stripping and entrainment. This concern was discussed but no nuclear safety concern was identified. The amount of fissile material in one PR batch is small as will be confirmed by calculation in item 1 above. Accumulation of fissile material in the PRCD is also thought not possible for more than 1 batch. At the end of the PR cycle, all of the material will be circulated back to the PR.

\section{(5) Accumulation in the Organic Evaporator}

Organic materials collected in the $\mathrm{OE}$ are recirculated to the PRCD to rernove heavy organics collected during steam distillation. After precipitate reactor operation is completed, the organic-water mixture is mixed with high speed agitation to extract radionuclides, primarily Cs-137, from the organics prior 
to evaporation. Eventually, the aqueous will be returned to the PR at the end of the OE cycle via the PRCD.

It is expected that some fissile material may reach the OE. However, this concern is bounded by the previous concern in the PRCD, and fissile material will eventually end up in the PR.

(6) Decontamination Route.

This is not a concern since material in the SPC sump is expected to be transferred back to the PR for processing. In the case where the sump content is routed to the RCT, worst case scenarios considered in the sump (item 3 above) are expected to be the bounding cases.

\section{Chemical Process Cell}

The discussion for the Chemical Process Cell concentrated on the Slurry Receipt and Adjustment Tank (SRAT) process. A worst case scenario in the Slurry Mix Evaporator (SME) is already documented. 8 The nuclear criticality concerns in the Chemical Process Cell will also be addressed in the DWPF Technology Issue T.I. 24.1.

Following are the two nuclear safety issues in the SRAT:

(1) There is a concern that plutonium oxide may be dissolved in the mercury in the mercury trap in the SRAT. 9 It may accumulate over time in the mercury trap and cause a nuclear safety concern. This question is raised in reference 7 and will be resolved experimentally. The distribution of plutonium will be experimentally determined between the aqueous sludge slurry phase and the mercury phase using both simulated sludge doped with known amount of plutonium and Tank 42 sludge. A nuclear criticality safety analysis will be performed to resolve this concern. Although the original concern and the follow-up experiments involve only plutonium, the nuclear criticality analysis calculation will include uranium with the maximum enrichment of $1.2 \% \mathrm{U}-235$ as documented in batch 2 (reference 3).

(2) Another concern was also discussed relating to fouling of the SRAT vessel and subsequent clean-up procedure. This concern will be resolved by nuclear criticality safety analysis. In this scenario, fouling occurs in the SRAT by a $1 / 4$-inch thick material around the coils. The fissile material concentration is assumed to be uniform and the same as in the original solid. During clean up, nitric acid is expected to concentrate plutonium oxide. 


\section{Melter}

The nuclear criticality concerns in the DWPF Melter have also been discussed before. 8 Following are additional scenarios that were discussed during the meetings on DWPF nuclear criticality. These issues will also be addressed in the DWPF Technology Issue T.I. 24.1.

There are primarily two additional issues related to the nuclear safety of the DWPF melter.

(1) There has been a concern about plutonium accumulation in the melter which could be a potential source of a nuclear criticality incident during the melter's 2-year life. 10 This concern was heightened lately due to observation of noble metals at the bottom of a small-scale research melter. 11 The DWPF Technology Issue T.I. 24.1 will attempt to resolve this issue by experimentally measuring the accumulation of fissile material in the Shielded Cells' Melter during the processing of Tank 51 radioactive sludge. Nuclear safety calculation will then performed using these experimental data.

(2) The second melter issue raised during the parel discussion was that fissile material may segregrate and accumulate at the bottom of a canister. It will be determined if the fissile material in a canister is of critical mass based on amounts in batch 1 through $4^{2-5}$. If it is, a nuclear safety analysis will be completed to determine if a canister filled with glass is a safe container, with respect to nuclear criticality, if all fissile materials in the glass segregate and accumulate at the bottom of a canister.

\section{The Process Vent and Off-Gas Systems}

There have been situations, both on-site and off-site, indicating that solids accumulation in the vent systems can be a significant nuclear safety concern. Although it is not believed that this will be the case in the DWPF's process vent and off-gas system, we are not aware of information or documentation indicating that this problem has been examined.

It is reccomended that, after cold chemical runs are completed, the process vent and off-gas systems should be inspected to establish if solids accumulate in the ventilation systems. If solids acclimulation is significant, then these systems should be analyzed for a possible accumulation of fissile isotopes and the consequences of the accumulation analyzed, in terms of potential nuclear safety concerns. Results of these analyses will be documented. 


\section{Mercury Purification}

Water and mercury distilled from the SRAT during boil-up will be collected continuously in the Mercury Water Wash Tank (MWTT). Condensate will be transferred to the SRAT and SMECT. Undistilled mercury and amalgamated metals accumulate in the SRAT sump will be transferred to the MWTT.

Mercury will be washed with water to remove entrained sludge, formic acid and other contaminants. Washed mercury is transferred to the Mercury Purification Cell and washed with nitric acid to remove water insoluble salts. A final scrub is provided by passing mercury countercurrent with nitric acid through packed columns and water scrub streams. After analyzing to confirm the radioactivity is below detectable limits, the washed mercury is vacuum distilled and stored before shipment to $200-\mathrm{H}$ Area.

Dependent on the results of the T.I. 24.1, the mercury in the SRAT sump may contain sufficient plutonium to cause a concern. The mercury purification system may need to be analyzed if fissile material is present in sufficient quantity to be of concern.

\section{Recycle Collection Tank (RCT)}

All radioactive waste solution generated in the DWPF will be neutralized and transferred to the the waste farm through the Recycle Collection Tank. Contents of the RCT will be chemically adjusted to yield a solution of $1 \mathrm{M}$ free hydroxide and $0.04 \mathrm{M}$ nitrite. These levels of corrosion inhibitors will ensure adequate corrosion protection for the waste receipt tank in the Interim Waste Storage Facility.

In the RCT, solids precipitate when the contents are neutralized. Although fissile materials will not precipitate separately during treatment, the RCT system must be analyzed for nuclear safety, with respect to criticality, and the results from the analysis must be documented.

\section{Decontamination Waste Treatment Tank}

This concern is also related to the process vent and off-gas systems. HEME and HEPA filters are the active filter elements used in the process vent and off-gas systems. These spent filter elements will be processed in the Decontamination Waste Treatment Tank (DWTT). Since HEME and HEPA are both composed of fiberglass, they can be 
reduced to a slurry in a dilute sodium hydroxide solution. Subsequent treatment with nitric acid will dissolve all of the fiberglass solids.

There is a concern that solids accumulation in these spent filter elements could lead to separation and accumulation of fissile material in the DWTT after the filter element is dissolved. Although it is not believed that (1) significant fissile material accumulates in the filter element, and (2) fissile material will preferentially separate from the other solids and accumulate in the DWTT, this process should be analyzed with respect to nuclear safety and the results documented.

\section{References}

1. D. T. Hobbs and S. D. Fleischman, "Fissile Solubility and Monosodium Titanate Loading Tests," WSRC-RP-92-1273, February 12, 1993

2. J. R. Fowler, "Major Waste Processing Treams for Waste Glass from Sludge Batch 1," WSRC-RP-89-129, April 21, 1989.

3. J. R. Fowler, "Major Waste Processing Treams for Waste Glass from Sludge Batch 2," WSRC-RP-89-130, April 21, 1989.

4. J. R. Fowler, "Major Waste Processing Treams for Waste Glass from Sludge Batch 3," WSRC-RP-89-131, April 21, 1989.

5. J. R. Fowler, "Major Waste Processing Treams for Waste Glass from Sludge Batch 4," WSRC-RP-89-132, April 21, 1989.

6. L. F. Landon, "Program to Address Present Problems with Salt Processing Cell Decanters and Reactor Fouling," DPST-88-851, September 20, 1988.

7. L. F. Landon/PHEF Task Team, "Executive Summary of HAN Precipitate Hydrolysis Experimental Facility," WSRC-RP-89-01, April 3, 1989.

8. WSRC-RP-92-1186, "Basic Data Report Defense Waste Processing Facility Sludge Plant Savannah River Site 200-S Area (U)," July 1992.

9. R. E. Eibling, "Plutonium Accumulation in the Slurry Receipt Adjustment Tank," DPST-82-766, August 10, 1982.

10. P. D. Soper, "Plutonium-239 Accumulation in the DWPF Melter," DPST-82-673, July 1, 1982. 
11. D. F. Bickford, P. M. Allen, and S. M. Peters, "Noble Metal Accumulation and Recovery in the DWPF Waste-Glass Melter," DP-MS-88-231, April 10, 1989. 

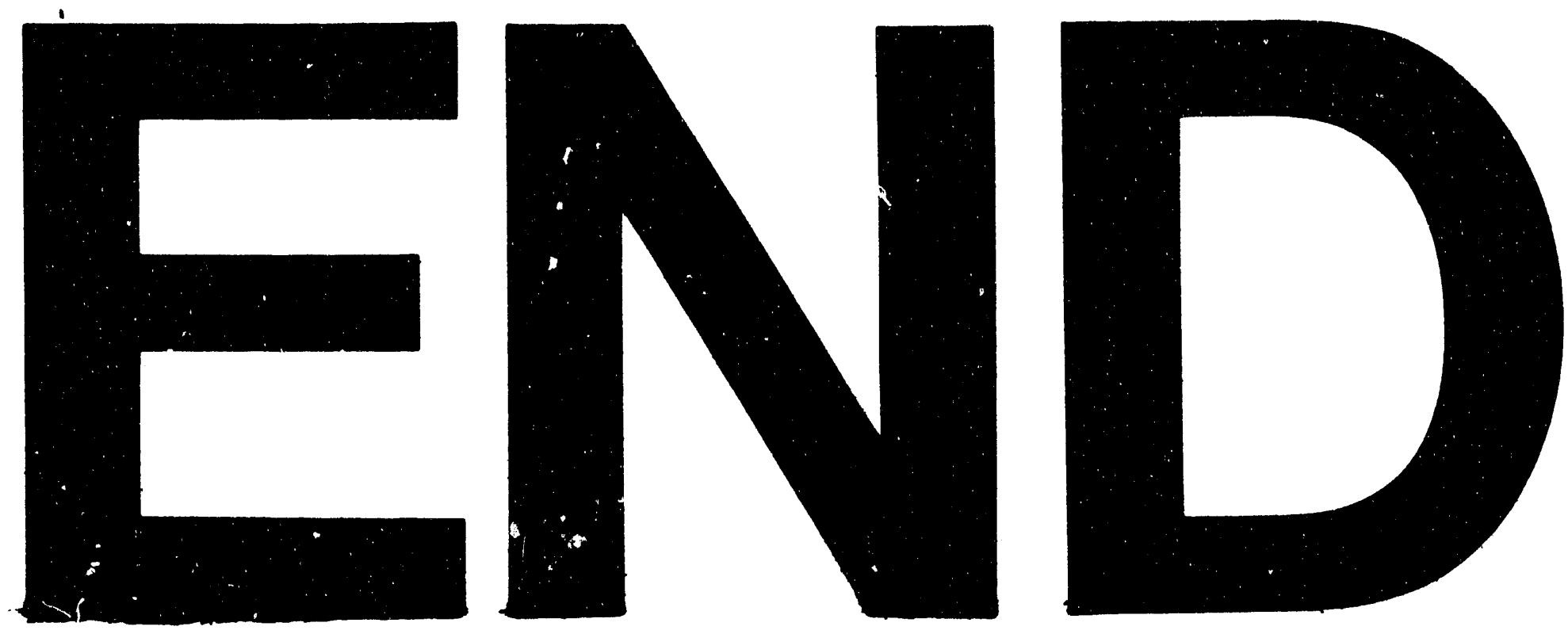

$\sim$

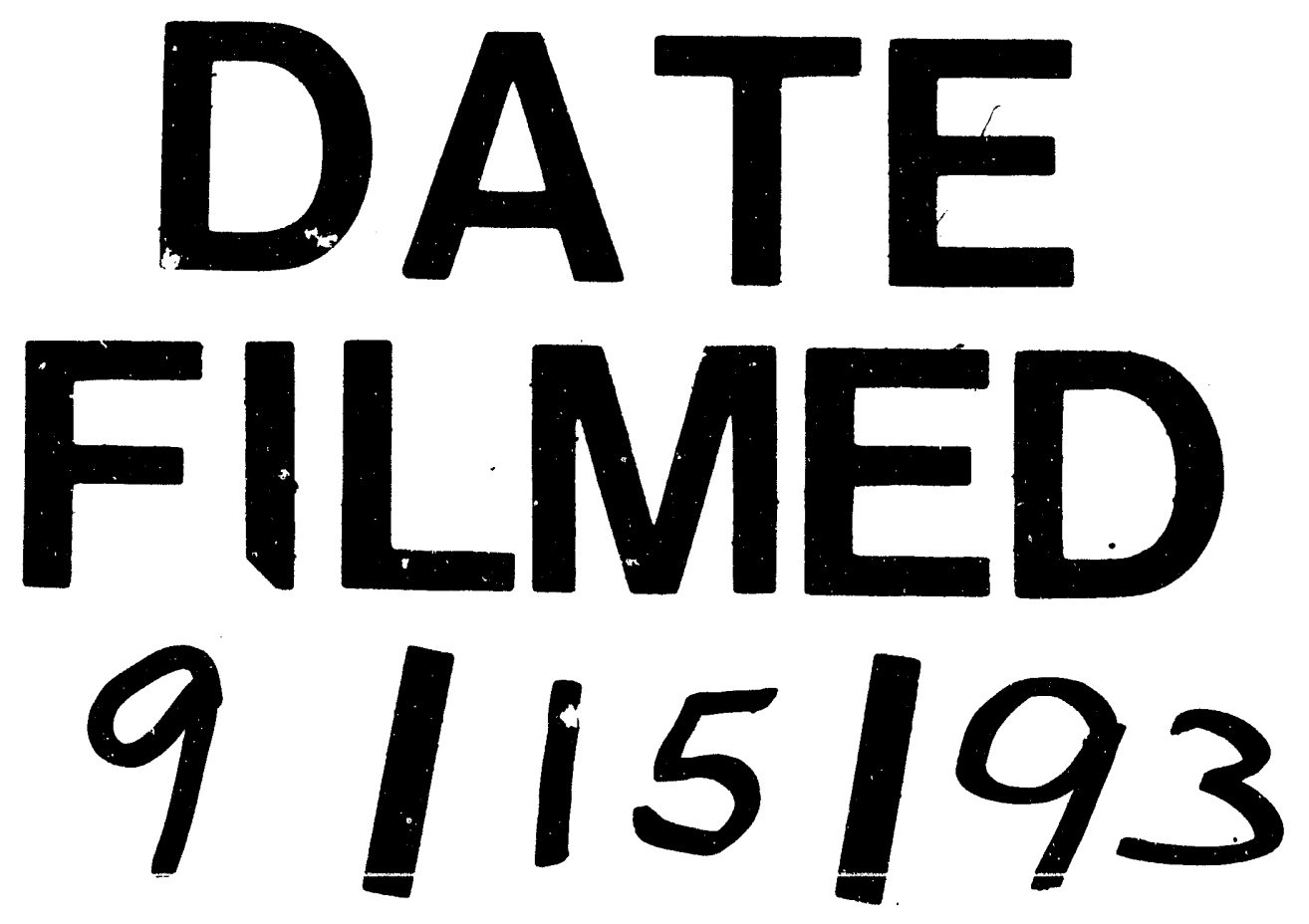




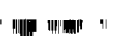

